\title{
E-learning for carers
}

Olga Solberg*, Jeanette Ullmann Miller, Synne Heivang, Mads Bjerke

From 5th European Conference on Rare Diseases (ECRD 2010)

Krakow, Poland. 13-15 May 2010

The Centre for Rare Disorders is an interdisciplinary, nationwide competence centre which offers information, counselling and seminars on a selected range of rare disorders.

The purpose of the e-learning programme in question is to improve quality of life for patients with Huntington's disease by increasing the carer's knowledge. Elearning and interactive sharing of information can be an effective and secure way of providing professionals with new knowledge. E-learning also functions as a tool for network-building.

\section{Methods/techniques}

The e-learning programme is organised as a module based compilation of knowledge and competence gathered by the Centre for Rare Disorders and its collaborators over the last 15 years. In addition to the modules, the users have shared information in on-line discussions. Their level of knowledge was evaluated through several tests.

\section{Security}

The participants received a password and username for logging on to the programme.

Published: 19 October 2010

doi:10.1186/1750-1172-5-S1-P13

Cite this article as: Solberg et al:: E-learning for carers. Orphanet Journal of Rare Diseases 2010 5(Suppl 1):P13.

*Correspondence: olga.solberg@rikshospitalet.no

Centre for Rare Disorders - Rikshospitalet, Oslo University Hospital,

Rikshospitalet, Oslo, 0027, Norway
Submit your next manuscript to BioMed Central and take full advantage of:

- Convenient online submission

- Thorough peer review

- No space constraints or color figure charges

- Immediate publication on acceptance

- Inclusion in PubMed, CAS, Scopus and Google Scholar

- Research which is freely available for redistribution

Submit your manuscript at www.biomedcentral.com/submit
Biomed Central 